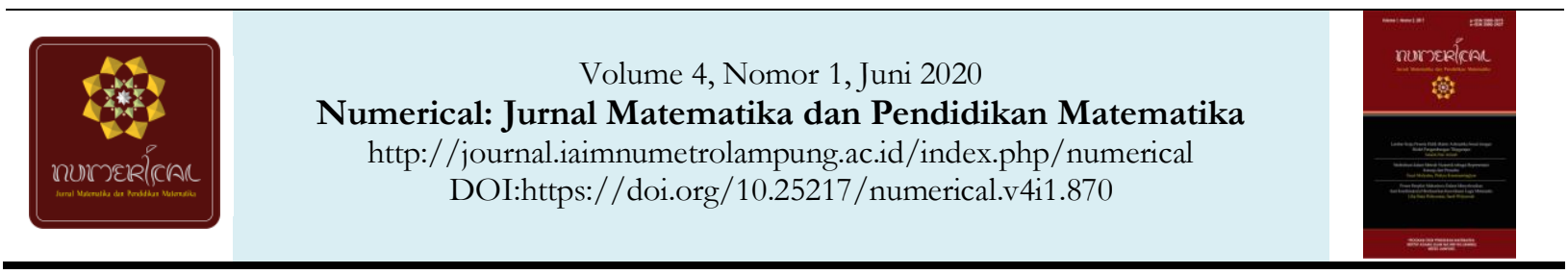

\title{
Ethnomathematics: Treasure Search Activity in the Musi River
}

\author{
Malalina Malalina ${ }^{1}$, Ratu Ilma Indra Putri², Zulkardi Zulkardi³ ${ }^{3}$ Yusuf Hartono4
}

${ }^{1}$ Universitas Tamansiswa Palembang, Indonesia

2,3,4 Universitas Sriwijaya, Indonesia

Correspondence: $\bowtie$ malalina@unitaspalembang.ac.id

\begin{tabular}{|c|c|}
\hline Article Info & Abstract \\
\hline Article History & Ethnomathematics is one of mathematics learning innovations which integrate \\
\hline Received: 27-04-2020 & cultures to preserve local cultural values. A treasure quest at Musi River Palembang \\
\hline Revised: 08-06-2020 & is included as a culture because it is the community activity with its unique \\
\hline Accepted: 09-06-2020 & characteristic carried out at Musi River to meet the necessities of life, and is passed \\
\hline Keywords: & $\begin{array}{l}\text { down from one generation to the next generation. The research aims to explain } \\
\text { aspects of mathematical computation to treasure quest at Musi River Palembang. A }\end{array}$ \\
\hline Ethnomathematics; & literature study is a method used in this research. Firstly, formulating research \\
\hline Mathematical Aspects; & problem was how the mathematical aspects connect to the finding of treasure quest \\
\hline Counting Aspects & at Musi River Palembang. Then, literature related to the problem of the study was \\
\hline & $\begin{array}{l}\text { reviewed. The next step was evaluating data based on the literature to answer the } \\
\text { research problem. After that, data analysis was conducted. Descriptive analysis was }\end{array}$ \\
\hline & used to analyze the data. Lastly, the data was interpreted to obtain a conclusion. The \\
\hline & interpretation showed that the treasure quest at Musi River had mathematical \\
\hline & $\begin{array}{l}\text { counting aspects namely, counting the number of human resources in a treasure } \\
\text { quest group; counting the wages for each person in the team based on his or her }\end{array}$ \\
\hline & duties; counting expenses required for a treasure quest; counting the number of \\
\hline & $\begin{array}{l}\text { objects obtained, and determining the sale price of the objects. The activity also } \\
\text { contained a mathematical concept in the mathematics learning of some subjects at }\end{array}$ \\
\hline & $\begin{array}{l}\text { VII grade of junior high school level namely, the operation of the material count, } \\
\text { social arithmetic, and sets. }\end{array}$ \\
\hline
\end{tabular}

\section{INTRODUCTION}

Indonesia consists of hundreds of islands, each island has a different culture so that Indonesia has a diverse culture. At present, the culture of Indonesia has begun to fade by the effects of globalization. The influence of globalization causes degradation or shifts the existing cultural values in Indonesia [1][2]. Besides, local cultures which are national identity and features have begun to fade by foreign cultures [3]. One of the innovations so that Indonesian culture does not fade by globalization, culture must be integrated with learning, because learning is one way to instil cultural values used in learning [4].

The learning has to be revolutionized by considering aspects of local culture. Cultural integration in learning mathematics is known as ethnomathematics [5]. Ethnomatemics learning can strengthen national identity [6]. Besides, ethnomathematics can be used to overcome students learning difficulties by connecting local culture with mathematical learning topics [7]. The same thing was expressed by Rosa and Shirly, mathematics lessons that are connected with student culture can help students understand their own culture and understand mathematics material in the schools [8]. 
Significance of the existence of mathematics is rarely beneficial to the students that math becomes abstract and tend to be filled with numbers that are not meaningful [9]. Though math is a subject that can be used as a tool for other sciences [10]. To facilitate the significance of mathematics then Ubitarian sparked an approach that integrates mathematics learning in mathematics learning culture [11]. As a practitioner education is the responsibility to provide solutions to the problems in education. Involving culture in mathematics learning activities into the alternatives that can be developed with the goal in addition to introducing the culture and instil a love of the heritage of Indonesia, the integration of culture in learning mathematics can be easier to understand the material presented is more realistic [12].

Mathematical learning innovation to overcome students learning difficulties is by connecting local culture and topics of learning mathematics known as ethnomathematics [7]. Meanwhile, Marsigit revealed the innovation of mathematics learning for teachers developing ethnomathematics based learning is also relevant for mathematics learning [13]. Learning mathematics using ethnomathematics makes learning more interesting while preserving culture and strengthening the role of mathematics education and supporting human resource development [14][15]. Thus, ethnomathematics is one of the innovations in mathematics learning by integrating culture while preserving local cultural values.

Ethnomathematics is practised by community groups, tribes, labourers, children, professionals and others [11]. According to Bishop ethnomathematics have the characteristics of a mathematical aspect includes counting, specify locating, measuring, designing, playing and explaining [16]. There are five categories in ethnomathematics research, which are related to the changing history of mathematics traditionally told, mathematical analysis related to the traditional culture of indigenous people, exploring mathematics from various groups in daily life activities and the relationship between ethnomathematics and mathematics education and social influence, culture, politics towards the ethnomathematics development [17]. In the development of Ethnomathematics in Indonesia, said by Susilo and Widodo there are two forms namely ethnomathematics as a learning approach and as a research approach [6].

Ethnomathematics researches which have done in activity-based mathematics culture such as computing, counting, measuring, and create a design [18]-[21]. Zaenuri stated that included in the cultural elements are daily activities, cultural heritage, traditional food or human activities making patterns, designing, calculating that is applied in activities of daily life [22]. While Koentjaraning, at cultural elements, includes language, knowledge systems, social organization, equipment and technology systems, livelihood systems, religious systems and arts [23].

Palembang culture also contains aspects of ethnomathematics. One of them can be used as a context for learning mathematics is the activity of searching for treasure in Sungai Musi. The search for treasure in the Musi River is included in the concept of culture because it is an activity of a group of people who have characteristics to meet the necessities of life (livelihood) which are passed down from generation to the next generation. Besides, the activity of searching for treasure in the Musi River is one type of ethnomathematics research that exploring mathematics from various groups in the activities of daily life. Indirectly, treasure seekers have carried out activities related to mathematical concepts. Different from previous researches, it will focus on aspects ethnomathematics counting on the activity of treasure hunt in Musi River. The search for treasure on the River Musi more terms outside the realm of mathematics as well as the findings of the search results a treasure trove of objects just seen from the economic side. 
Treasure hunters are a group of community life activities that look for treasure at the bottom of the Palembang Musi River every day. The treasures referred to are historical relics that existed at the bottom of the River starting from the Sriwijaya era, Sultanate of Palembang Darussalam, Kolonian until the era of independence. Based on the explanation above, the purpose of the problem in this study is to explain the mathematical aspects of counting in the search for treasure in the Musi River in Palembang.

\section{RESEARCH METHOD}

This study used the literature study method. According to Susilo and Widodo, there are stages in the study of literature namely problem formation, literature search, data evaluation, analysis and interpretation [5]. The first stage is the formation of the problem, the formation of the problem is done when preparing the problem formulation. The second stage is the search for literature in the form of journal articles, proceeding articles, books, theses, dissertations, lecture material that supports the formulation of the problem. The third stage is data evaluation, which is identifying data based on literature that can answer the problem formulation. The fourth stage of data analysis is analyzing data to answer the problem formulation. And the last stage of the five interpretations of the data is used to get conclusions from the results of data analysis. The descriptive analysis technique used in this study.

\section{RESULT AND DISCUSSION}

\section{Activities to Find Treasure}

Musi River is a part of Palembang city starting from downstream to upstream. Musi River has a very experienced long history Sriwijaya, Palembang Darussalam, Kolonian to the Independence era. So, there are many heritage objects have historical value. According to Sudirman Tegoeh, Head of Culture Office of Palembang City, Palembang is a very old city with the age of 1335 years. The existence of the River has passed through various eras and become a trade route, an inverted boat that contains a lot of goods and settles on the Riverbed is not only valuable in economic terms but also terms of historical value. Therefore, the remains of objects in the $17^{\text {th }}$ until the $18^{\text {th }}$ century which is the era of the Sriwijaya kingdom are still visible with many found in the area of the Palembang Musi River [24].

Community on the banks of the Musi River in a hereditary activity treasure hunt in the bottom of the Musi River to make ends meet when getting objects that have economic value. But indirectly, the treasure hunter has conducted activities about mathematical concepts. People are looking for treasure do a treasure hunt activity learned from their parents' generation, and they will teach to the next generation. Treasure hunt activity at Musi River using simple tools that boat by using the machine is used as a means of transportation for a treasure hunt, a compressor and hoses as oxygen is used divers to perform dives breathing down to the riverbed. Hose used to suck up objects to climb to the top of the boat, but it also uses hands to dredge riverbed to feel valuable objects in the river, the tool sieving sand (table sieve) is used to separate sand or soil with valuable objects [24]-[26]. Aktivitas treasure hunt on the Musi River in Palembang for as a society be used as a daily livelihood passed down from generation to generation.

Dominic defines the culture in two respects, namely referring to objects or events that can be observed in the environment and human guidance refers to organize experience and their 
perception [16]. While Zaenuri et al cultural elements are daily activities, cultural heritage, traditional food or human activity pattern making, designing, calculating applied in activities of daily life [22]. While Koentjaraningkat cultural elements, includes language, knowledge systems, social organization, systems and technology equipment, systems livelihood, religion and art system [23].

Based on the above definition of treasure hunt activity in Musi River is included in the concept of culture as it is an activity of groups of people who have characteristics to meet the necessities of life (livelihood) is inherited from generation to generation in the Musi River.

\section{Ethnomathematics}

Ethnomathematics was first introduced by a Brazilian mathematician named Ubiratan D'Ambrosio. Ethnomathematics consists of the word ethno - mathema - tics [27]. The "ethno" has a very broad meaning that refers to facts and phenomena as well as the social, cultural and mythical environment, "mathema" has the meaning of understanding, knowing, explaining, doing an activity, The word "tics" is a technique [27]. Ethnomathematics research category is related to changes in the history of mathematics traditionally told, mathematical analysis related to the traditional culture of indigenous peoples, exploring mathematics from various groups in daily life activities and the relationship between ethnomathematics and mathematics education as well as social, cultural, political influences on the development of ethnomathematics [17]. Research on treasure search activities in the Musi River is ethnomathematics research with the third type exploring the mathematics of various groups in daily activities.

As according to Bishop ethnomathematics has characteristics of mathematical activities, mathematical activities in ethnomathematics follow [16]:

a. Counting

The counting activity is associated with the numbers used by the cultural group.

b. Locating

Locating is concerned with defining the position of the object.

c. Measuring

Measuring activities generally use a variety of non-standard measurements. Each cultural group measures time, liquid and weight objects in different ways and tools.

d. Designing

The design activity is related to making patterns that are used to create objects.

e. Playing

Playing deals with a variety of traditional games and traditional dances in society that involve types of mathematical reasoning, probability and strategic thinking.

f. Explaining

Explaining refers to various cognitive aspects of questioning and conceptualizing the environment, for example, giving direction to one place and another, understanding graphics, patterns, and symbols.

The characteristics of the mathematical activities examined in this article are the mathematical aspects of counting. Following are the results of ethnomathematical research as a culture-based activity in the community that is integrated with mathematics learning. Community 
activities in the Gebang Fish Market, The results of the study show that (1) community activities in the Gebang Fish Market have ethnomathematics value and can be used as teaching materials in junior high school learning; (2) Community activities in the Gebang Fish Market have developed and practised by the community down, such as adding, reducing, numerating and calculating related to mathematical concepts; (3) ethnomathematics in the Gebang Fish Market community as local knowledge provides an understanding of mathematical concepts at the junior high school[18].

Community activities in the Payakumbuh Livestock Market namely Marosok Tradition, this study has the conclusion that the Marosok Tradition is the process of buying and selling livestock containing ethnomathematics values. The agreement of the buying and selling process is done by shaking hands with the seller and the buyer with the seller's hand and the buyer is covered by fabric if an agreement is made then the fingers will stop fingering. The tradition of buying and selling is related to mathematics learning of social arithmetic material with the material selling price, buying price, capital, profit, loss and others [19].

Ethnomathematics exploration in the syllable, the results of this study have the conclusion that the operation of numbers has a relationship with the syllable such as addition, subtraction, multiplication and division [20]. Ethnomathematics in the culture of the Larantuka Community, the results of the study concluded that there is a mathematical activity in the construction of traditional houses, namely the activity of calculating the materials needed for housing construction has been calculated by "Profit Belewet" [21].

\section{The Mathematical Aspect of Calculating}

The treasure search activities in the Musi River contain mathematical aspects of counting which are characteristic of ethnomathematics. The following will explain the counting aspects of activities carried out in the search for treasure in the Musi River:

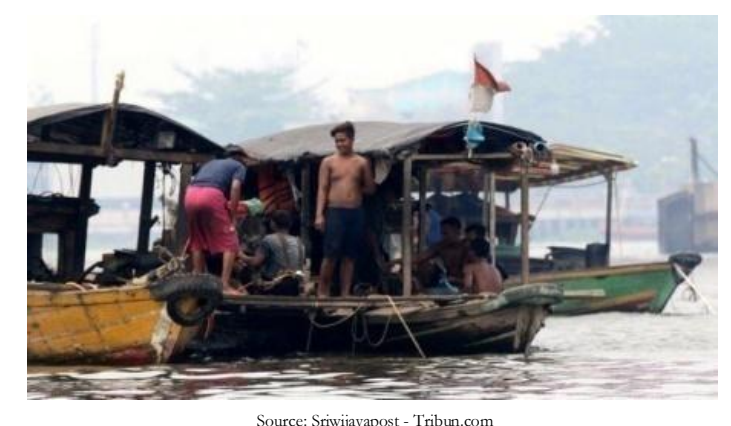

Figure 1. One of the Treasure Seekers in the Musi River

Figure 1 above is one of the ships model and treasure search groups in the Musi River. In the process of searching for treasure in the M River, the initial step taken by the treasure hunters is to count a lot of human resources in one treasure search group. Besides, in the search for treasure also calculates the wages received for each human resource in one team according to their respective duties and calculates the expenses needed in one treasure search. This is done to determine the costs incurred in the process of searching for treasure in one search. The length of time needed in one search for treasure must also be taken into account. When connected with the mathematics material of Class VII Junior High School, this mathematical aspect is integrated into the material Numbers, sets and social arithmetic. 
In addition to human resources involved in the mathematical aspects of counting, some objects are found in the search for treasure also contains mathematical aspects of counting. Figure 2 below are objects found in Palembang Musi River.

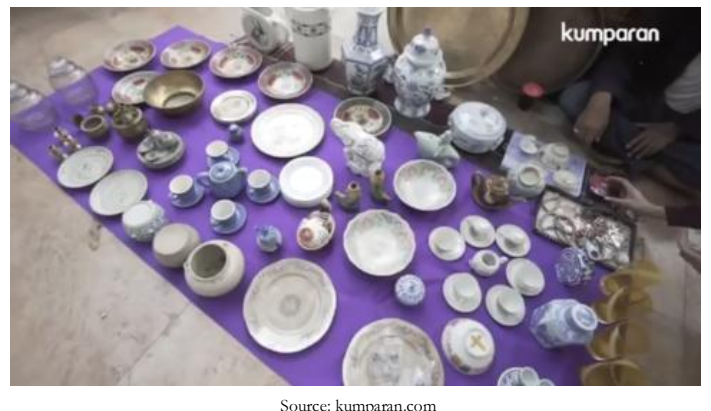

Figure 2. Findings in the Palembang Musi River

Figure 2 above are the findings in the River Musi, these findings are the findings from the kingdom Sriwijaya, Palembang Darussalam, Colonial, until the time of Independence. Mathematical aspects of the findings in the Musi River, which count the number of objects obtained and calculate the sale price obtained objects. The number of objects in the get and set prices influenced by centuries estimates obtained objects. If the material studied in seventh-grade junior high math then this mathematical aspect related to the substance of Numbers, associations and social arithmetic.

Based on the explanation above, the search for treasure in the Musi River has a mathematical aspect that is counting by the mathematics curriculum for the seventh-grade junior high school, namely integer operation material, social arithmetic and sets. This is consistent with previous research, Sulaiman [18], Choirudin [4] Annisa [19], Alhadi [20], Ningsih [28] and Agustini [21] stated that there were counting activities contained in cultural concepts and could be used as contexts in mathematics learning for class VII junior high school.

Figure 3 The following is a chart of the ethnomathematics relationship to treasure search activities in the Musi River which can be linked to the Mathematics material for Grade VII Middle School with the counting aspect. 
Numerical: Jurnal Matematika dan Pendidikan Matematika, 4(1), Juni 2020, 31-40

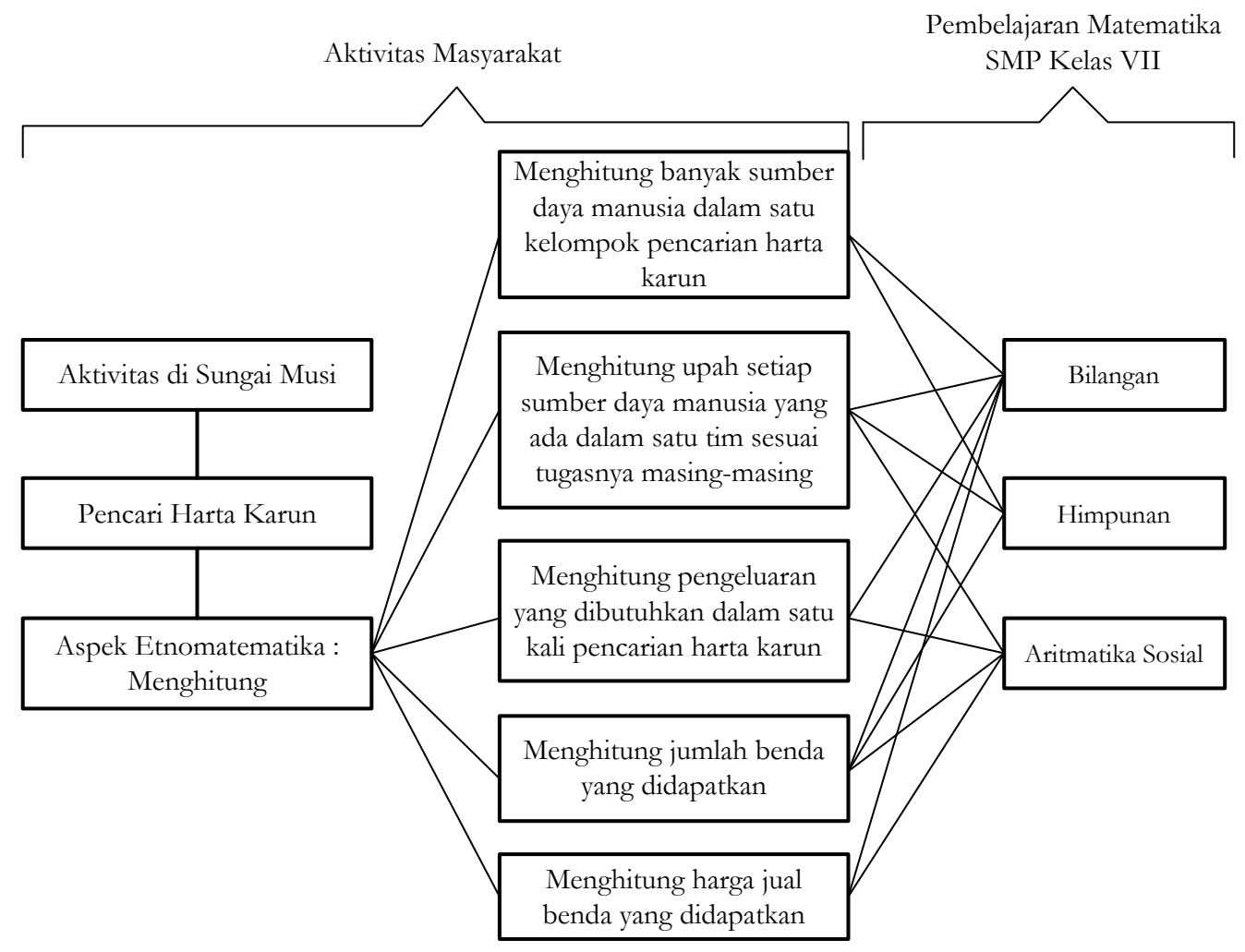

Figure 3. Relationship of Mathematical Aspects of Calculating and Learning Mathematics Junior High School Class VII

From Figure 3 above it can be seen that the community activity in the search for treasure in the Musi River can be used as a context in learning mathematics. Learning at the VII grade junior high school level that can be linked to integer operation material, social arithmetic and sets. Thus it can be concluded that many cultural results can be used in learning mathematics. This culture has been carried down for centuries, so it should be preserved by integrating culture with mathematics learning, known as ethnomathematics. Same as the results of previous studies namely Sulaiman [18], Choirudin [4] Annisa [19], Alhadi [20], Ningsih [28] and Agustini [21], treasure search activities in the Musi River also contain ethnomathematics. The counting aspect activities can be used as the context of mathematics learning for seventh grade junior high schools, namely numbers, social arithmetic and sets. By using local culture in Palembang, the value of this culture will continue to be preserved for generations.

\section{CONCLUSIONS AND SUGGESTIONS}

It can be concluded that the activities of treasure search activities have ethnomathematics values. There are five mathematical aspects of counting in treasure search activities in the Musi River. Counting many human resources in one treasure search group; Calculate the wages of each human resource in a team according to their respective duties; Calculate expenses needed in one treasure search; Count the number of objects obtained; Determine the selling price of the objects obtained. Treasure search activities contain mathematical concepts in mathematics learning at the VII grade of junior high school, namely arithmetic, social arithmetic and set material. In this study, only one mathematical aspect is calculated, so the suggestion for further research is to use 
the six mathematical aspects of ethnomathematics based on interviews and direct observation of the people who are searching for treasure in the Musi River.

\section{REFERENCES}

[1] G. Budiarto, "Indonesia dalam Pusaran Globalisasi dan Pengaruhnya Terhadap Krisis Moral dan Karakter," Jurnam PAMATOR, vol. 13, no. 1, pp. 50-56, 2020, doi: https://doi.org/10.21107/pamator.v13i1.6912.

[2] R. Bukido, A. Lundeto, and R. Gonibala, "Tradition and Culture Tumbilotohe Community in North Sulawesi," Journal of Environmental Treatment Techniques, vol. 8, no. 1, pp. 247-249, 2020.

[3] I. Wahab and N. Amaliyah, "Identifikasi Cerita ANak Berbasis Budaya Lokal Untuk Membudayakan Literasi di SD," Satya Widya, vol. XXXV, no. 2, pp. 176-185, 2019, doi: https://doi.org/10.24246/j.sw.2019.v35.i2.p176-185.

[4] Choirudin Choirudin, Eka Fitria Ningsih, M. Saidun Anwar, Intan Ratna Sari, and Suci Amalia, "Pengembangan Perangkat Pembelajaran Etnomatematika Pada Situs Purbakala Pugung Raharjo," Pi: Mathematics Education Journal, vol. 3, no. 1, pp. 18-27, 2020, doi: https://doi.org/10.21067/pmej.v3i1.3755.

[5] C. Agus, P. A. B. Cahyanti, B. Widodo, Y. Yulia, and S. Rochmiyati, "Cultural-Based Education of Tamansiswa as a Locomotive of Indonesian Education System," Universities as Living Labs for Sustainable Development. World Sustainability Series. Springer, Cham, pp. 471-486, 2019, doi: https://doi.org/10.1007/978-3-030-15604-6_29.

[6] B. E. Susilo and S. A. Widodo, "Kajian Etnomatematika dan Jati Diri Bangsa," IndoMath. Indonesia Mathematics Education, vol. 1, no. 2, pp. 121-128, 2015, doi: http://dx.doi.org/10.30738/indomath.v1i2.2886.

[7] C. S. Ubayanti, H. Lumbantobing, and M. M. H. Manurung, "Eksplorasi Etnomatematika pada Sero (Set Net) Budaya Masayarakat Kokas Fakfak Papua Barat," Jurnal Ilmiah Matematika dan Pembelajarannnya, vol. 1, no. 1, pp. 12-21, Feb. 2016.

[8] M. Rosa and L. Shirley, "Introduction," in Current and Future Perspectives of Ethnomathematics as a Program, Hamburg: ICME 13, 2016.

[9] Apri Wahyudi and Choirudin, "Pengembangan Alat Peraga Pembelajaran Matematika Materi Perkalian Berbasis Montessori," Jurnal Manajemen Pendidikan Islam Al-Idarah, vol. 4, no. 2, pp. 33-39, 2019.

[10] Subandi Subandi, Choirudin Choirudin, Mahmudi Mahmudi, Nizaruddin Nizaruddin, and Hermanita Hermanita, "Building Interactive Communication with Google Classroom," International Journal of Engineering \& Technology, vol. 7, no. 2.13, pp. 460-463, 2018.

[11] U. D'Ambrosio, "Ethnomathematics and its Place in the History and Pedagogy of Mathematics," in Ethnomathematics, Challenging Eurocentrism in Mathematics Education, Albany: State University of New York Press`, 1997, pp. 13-24.

[12] H. Nizar, R. I. I. Putri, and Z. Zulkardi, "Developing Pisa-Like Mathematics Problem Using The 2018 Asian Games Football And Table Tennis Context," Journal on Mathematics Education, vol. 9, no. 2, pp. 183-194, Jun. 2018, doi: https://doi.org/10.22342/jme.9.2.5246.183-194. 
[13] Marsigit, D. S. Setiana, S. Hardiarti, and R. Condromukti, "Pengembangan Pembelajaran Matematika Berbasis Etnomatematika," in Prosiding Seminar Nasional Etnomatnesia, Yogyakarta, Desember 2017.

[14] W. S. Dominikus, "Pembelajaran Matematika Berbasis Etnomatematika (PMBE)," presented at the Seminar Nasional Pendidikan Matematika, Kupang, Nusa Tenggara Timur, Jun. 2019.

[15] Choirudin, "Efektifitas Pembelajaran Matematika Dengan E-Learning Berbasis Schoology," masters, Universitas Terbuka, 2015.

[16] W. S. Dominikus, Etnomatematika Adonara. Kupang: Media Nusa Creative, 2018.

[17] N. Naresh, "The role of a critical ethnomathematics curriculum in transforming and empowering learners," Revista Latinoamericana de Etnomatemática, vol. 8, no. 2, 2015.

[18] H. Sulaiman, "Aktivitas Matematika Berbasis Budaya pada Masyarakat Pesisi di Pasar Ikan Gebang Kabupaten Cirebon,” MaPan: Jumal Matematika dan Pembelajaran, vol. 7, no. 1, pp. 61-73, 2019, doi: https://doi.org/10.24252/mapan.2019v7n1a5.

[19] H. Annisa, M. H. Asnawi, and E. Susanti, "Pemecahan Masalah Matematika (Aritmatika Sosial) Menggunakan Tradisi Marosok," in Prosiding SI MaNIs (Seminar Nasional Integrasi Matematika dan Nilai-Nilai Islami), Malang, 2020, pp. 285-288, http://conferences.uinmalang.ac.id/index.php/SIMANIS/article/view/957.

[20] F. A. Ahadi, Zaenuri, and A. N. Cahyono, "Exploration of Ethnomatematics in the Samin Tribe and Its Relationship with Mathematical Concepts," Unnes Journal of Mathematics Education Research, vol. 10, no. 2, pp. 184-189, Jan. 2020.

[21] N. K. A. Agustini, S. I. Leton, and A. J. Fernandez, "Studi Etnomatematika Pada Budaya Masyarakat Larantuka," Asimtot : Jumal Kependidikan Matematika, vol. 1, no. 1, pp. 27 - 32, 2019, doi: https://doi.org/10.30822/asimtot.v1i1.95.

[22] Zaenuri, A. W. P. B. Teguh, and N. Dwidayati, "Ethnomathematics Exploration on Culture of Kudus City and Its Relation to Junior High School Geometry Concept," International Journal of Education and Research, vol. 5, no. 9, pp. 161-168, Sep. 2017.

[23] Y. Malasari and C. Darmawan, "Budaya Adat Pengantin Melayu RIau Dalam Pengembangan Budaya Kewarganegaraan," HUMANIKA, vol. 24, no. 1, 2017, doi: https://doi.org/10.14710/mkmi.\%25v.\%25i.1-9.

[24] Kumparan, "Benda Kuno di Sungai Musi Dihargai hingga Miliaran Rupiah," 2018.

[25] antaranews.com, "Kisah penyelam Sungai Musi, pemburu harta karun Sriwijaya," 2019.

[26] DetikNews, "Geger Harta Karun Sriwijaya, Warga Temukan Cincin-Uang Emas," 2018.

[27] U. D'Ambrosio and M. Rosa, "Ethnomathematics and Its Pedagogical Action in Mathematics Education," in Ethnomathematics and its Diverse Approaches for Mathematics Education, 2017, pp. 285-305.

[28] Eka Fitria Ningsih, Santi Widyawati, Mahmudi, and Wahyu Kusumaningtyas, "Ethnomathematics in Traditional Games Java Jiting-Jitingan: An Approach to Improve the Quality of Mathematics Learning," WMA, 2018, doi: https://doi.org/10.4108/eai.24-12018.2292400. 
Numerical: Jurnal Matematika dan Pendidikan Matematika, 4(1), Juni 2020, 31-40

Malalina Malalina, Ratu Ilma Indra Putri, Zulkardi Zulkardi, Yusuf Hartono 